\title{
Oxidative Processing Lowers the Ice Nucleation Activity of Birch and Alder Pollen
}

\author{
Ellen Gute, and Jonathan P.D. Abbatt \\ Version Published PDF \\ Citation Gute, E., \& Abbatt, J. P. D. (2018). Oxidative processing lowers the ice \\ (published version) nucleation activity of birch and alder pollen. Geophysical Research \\ Letters, 45, 1647-1653. Doi: https://doi.org/10.1002/2017GL076357 \\ Publisher's Statement An edited version of this paper was published by AGU. Copyright \\ 2018 American Geophysical Union.
}

How to cite TSpace items

Always cite the published version, so the author(s) will receive recognition through services that track citation counts, e.g. Scopus. If you need to cite the page number of the author manuscript from TSpace because you cannot access the published version, then cite the TSpace version in addition to the published version using the permanent URI (handle) found on the record page.

This article was made openly accessible by $U$ of $T$ Faculty.

Please tell us how this access benefits you. Your story matters. 


\section{Geophysical Research Letters}

\section{RESEARCH LETTER}

10.1002/2017GL076357

Key Points:

- Birch and alder pollen washing water contains ice nucleating molecules

- Chemical oxidation by hydroxyl radicals under cloud water conditions decreases the ice nucleating ability of the pollen compounds

- Exposure to hydroxyl radicals drives substantial change at the molecular level, leading to a more oxidized pollen material

Supporting Information:

- Supporting Information S1

Correspondence to:

E. Gute,

ellen.gute@mail.utoronto.ca

\section{Citation:}

Gute, E., \& Abbatt, J. P. D. (2018). Oxidative processing lowers the ice nucleation activity of birch and alder pollen. Geophysical Research Letters, 45, 1647-1653. https://doi.org/10.1002/ 2017GL076357

Received 9 NOV 2017 Accepted 22 JAN 2018

Accepted article online 25 JAN 2018

Published online 6 FEB 2018
@2018. American Geophysical Union. All Rights Reserved.

\section{Oxidative Processing Lowers the Ice Nucleation Activity of Birch and Alder Pollen}

\author{
Ellen Gute $^{1}$ iD and Jonathan P. D. Abbatt ${ }^{1}$ iD \\ ${ }^{1}$ Department of Chemistry, University of Toronto, Toronto, Ontario, Canada
}

Abstract Pollen carry water extractable compounds with ice nucleating (IN) activity. This study investigates whether the hydroxyl radical, as the major atmospheric oxidant, can affect the IN activity of silver birch and grey alder subpollen particles under in-cloud conditions for deposition freezing mode conditions at $234 \mathrm{~K}$. It is found that oxidation increases the supersaturation ratio with respect to ice necessary for the onset of ice nucleation and decreases the fraction of particles which initiate ice nucleation. This reduction of IN activity under equivalent oxidation conditions does not occur with a mineral dust sample (Arizona Test Dust). Chemical analysis of fresh and oxidized pollen material indicates a change of molecular structure with a loss of conjugation and an increase in oxidized functional groups, such as carbonyls. This is the first demonstration that in-cloud oxidation may lower the IN abilities of biological particles such as pollen.

\section{Introduction}

Ice formation in the atmosphere directly influences the Earth's climate and hydrological cycle through its contributions to the radiative effects of clouds and through precipitation (Lohmann, 2006; Pruppacher \& Klett, 1997). Although global precipitation and radiative properties of clouds are influenced by the ice phase which is initiated by ice nucleating particles (INPs) (DeMott et al., 2011; Kanji et al., 2017), our knowledge about the ice forming processes and the particles involved is incomplete (Kanji et al., 2017). The ice phase in the atmosphere can either form through homogeneous freezing of super cooled liquid water droplets at temperatures below $-38^{\circ} \mathrm{C}$ or form through heterogeneous freezing where an INP initiates the freezing process from the liquid or gas phase.

Previous research has established that different airborne particles such as organic and inorganic particles, soot, crystalline salts, and biological particles are IN active (Hoose \& Möhler, 2012). Throughout its lifetime in the atmosphere, an INP can encounter changes to its shape, morphology, and chemical structure caused by physical or chemical processing. Processing of the particle may affect its ability to act as an INP, thus influencing cloud processes. For chemical processing, condensation of chemicals onto the particle with masking of the IN active sites along with the formation of a liquid layer around the INP and chemical alteration of the INP's surface by reaction have been investigated (Archuleta et al., 2005; Kanji et al., 2017; Sullivan, Miñambres et al., 2010, Sullivan, Petters et al., 2010; Sihvonen et al., 2014). Data from several studies suggest that the IN activity of an INP decreases as a result of chemical processing (e.g., Cziczo et al., 2009; Kanji, Florea, \& Abbatt, 2008; Wex et al., 2014). Much uncertainty still exists about the effect that oxidation as a form of chemical processing has on INPs. In particular, oxidation is likely to have a significant influence on organic INPs, given their numerous chemical functionalities that are susceptible to oxidative processes.

Fungal spores, bacteria, and pollen are known to efficiently nucleate ice under atmospheric conditions (Möhler et al., 2007) and will be exposed to oxidants after being emitted from their biogenic sources (Després et al., 2012). In particular, pollen grains carry large amounts of water extractable compounds on their surface (Breiteneder et al., 1989; Clarke et al., 1979; Schulte et al., 2009) and inside the grains, which are released primarily during rainfall (Schäppi et al., 1999). These smaller water extractable compounds, found to be polysaccharides (Dreischmeier et al., 2017), are IN active (Pummer et al., 2012). Another term used for pollen compounds released into the atmosphere are subpollen particles (SPPs) with submicron sizes (Steiner et al., 2015). A few prior studies of oxidation of biological/organic ice nucleating materials have been conducted, all via ozone oxidation (Attard et al., 2012; Brooks et al., 2014; Sarron et al., 2013; Wang \& Knopf, 2011). However, experiments assessing the effect of the most important oxidant in the atmosphere, the hydroxyl radical $(\mathrm{OH})$, have not been reported. In particular, $\mathrm{OH}$ can both react heterogeneously via gas- 


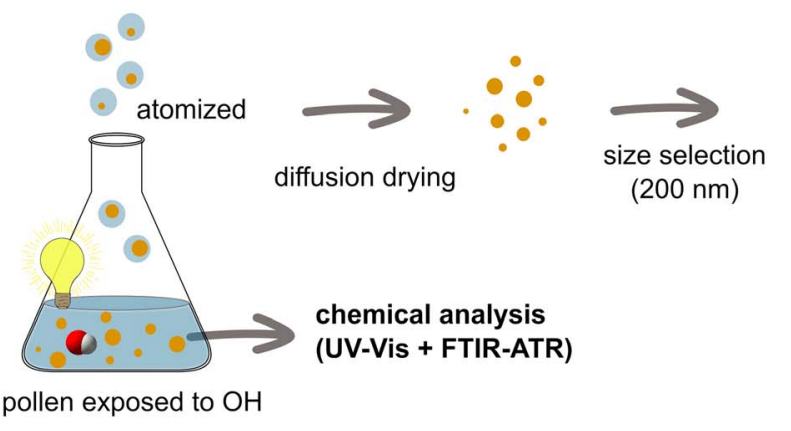

IN activity measurement (UT-CFDC)

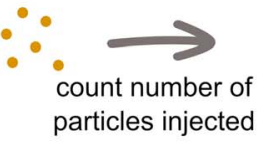
$(234 \mathrm{~K})$

Figure 1. Schematic of the experimental procedure. Exposure of samples to the hydroxyl radical in the aqueous phase and further preparation for ice nucleating activity measurements (University of Toronto Continuous Flow Diffusion Chamber) and chemical analysis (attenuated total reflection, ultraviolet-visible).

surface oxidation and react in clouds, given that cloud water $\mathrm{OH}$ is known to form via a number of sources (Lelieveld \& Crutzen, 1991).

The goals of this study were to investigate the effects of the hydroxyl radical on the IN activity of silver birch (Betula pendula) and grey alder (Alnus incana) pollen washing water, as common examples of biological IN active particles (Diehl et al., 2002; Dreischmeier et al., 2017; von Blohn et al., 2005). The pollen materials are exposed to $\mathrm{OH}$ under in-cloud conditions, and IN activity is evaluated for deposition freezing mode, where water vapor freezes onto an INP from a supersaturated vapor phase with respect to ice. IN activity changes are qualitatively related to chemical changes that occur upon oxidation.

\section{Materials and Oxidation Procedure}

Silver birch pollen (Betula pendula; collected between 28 and 30 March 2014 on land and roadside, South Czech Republic; contained $<2.3 \%$ contamination) and grey alder pollen (Alnus incana; collected on 27 February and 2 March 2017 from land side, South Czech Republic; contained $<7.1 \%$ contamination) were purchased as unprocessed (i.e., nondefatted) samples from Pharmallerga ${ }^{\circledR}$. In addition to the biological pollen samples, Arizona Test Dust (ATD; nominal 0-5 $\mu \mathrm{m}$, analysis 5,282 K) purchased from Powder Technology Inc. (Minnesota, USA) was tested in this study.

Pollen ( $0.2 \mathrm{~g}$ birch pollen, $0.4 \mathrm{~g}$ alder pollen) and dust ( $3 \mathrm{~g}$ ATD) samples were prepared as suspensions in $200 \mathrm{~mL}$ MilliQ ${ }^{\circledR}$ water, manually shaken for $5 \mathrm{~min}$ and left for $1 \mathrm{~h}$ to allow large and heavy particles to settle. The top part of the suspension, with the total organic carbon value being approximately $128 \mathrm{mg} / \mathrm{L}$ for birch and $183 \mathrm{mg} / \mathrm{L}$ for alder pollen for each prepared sample, was then transferred to an atomizer bottle where $500 \mathrm{mM}$ hydrogen peroxide (Sigma Aldrich, 30\%) was added and photolyzed using a $254 \mathrm{~nm}$ Pen-Ray ${ }^{\circledast}$ lamp to generate $\mathrm{OH}$ inside the aqueous-phase sample; the samples were stirred continuously. The amount of hydrogen peroxide added to the samples is equivalent to an $\mathrm{OH}$ concentration of approximately $4 \times 10^{-13} \mathrm{M}$ and therefore 1 to 2 orders of magnitude higher than expected in-cloud $\mathrm{OH}$ concentrations (Arakaki et al., 2013). OH concentration was quantified from the decay of benzoic acid (Buxton et al., 1988), which was added to the samples in a separate test and measured using highperformance liquid chromatography. A full description of the measurement and results are provided in the supporting information; a schematic of the experimental procedure is shown in Figure 1.

IN activity measurements were conducted by using the University of Toronto Continuous Flow Diffusion Chamber (UT-CFDC) (Kanji \& Abbatt, 2009). Particles were atomized using a Constant Output Atomizer (TSI Model 3076) and dried through two diffusion driers in series, before being size selected to $200 \mathrm{~nm}$ using a Differential Mobility Analyzer (TSI Model 3080). The number of particles in the sample flow was detected by a Condensation Particle Counter (CPC, TSI Model 3010) and set to approximately 400 to 1,000 particles per $\mathrm{cm}^{-3}$. A known number of particles were introduced into the UT-CFDC through a six-port stainless steel injector and represent $10 \%$ of the total flow of 2.83 LPM through the chamber. The remaining $90 \%$ of the air through the chamber is a dry nitrogen flow, keeping the sample air centered between the parallel walls of the chamber. The residence time of particles inside the chamber was $12 \mathrm{~s}$, allowing ice nucleation and growth of ice particles to sizes greater than $2 \mu \mathrm{m}$. Water droplets under this condition of $234 \mathrm{~K}$ and $12 \mathrm{~s}$ residence time 

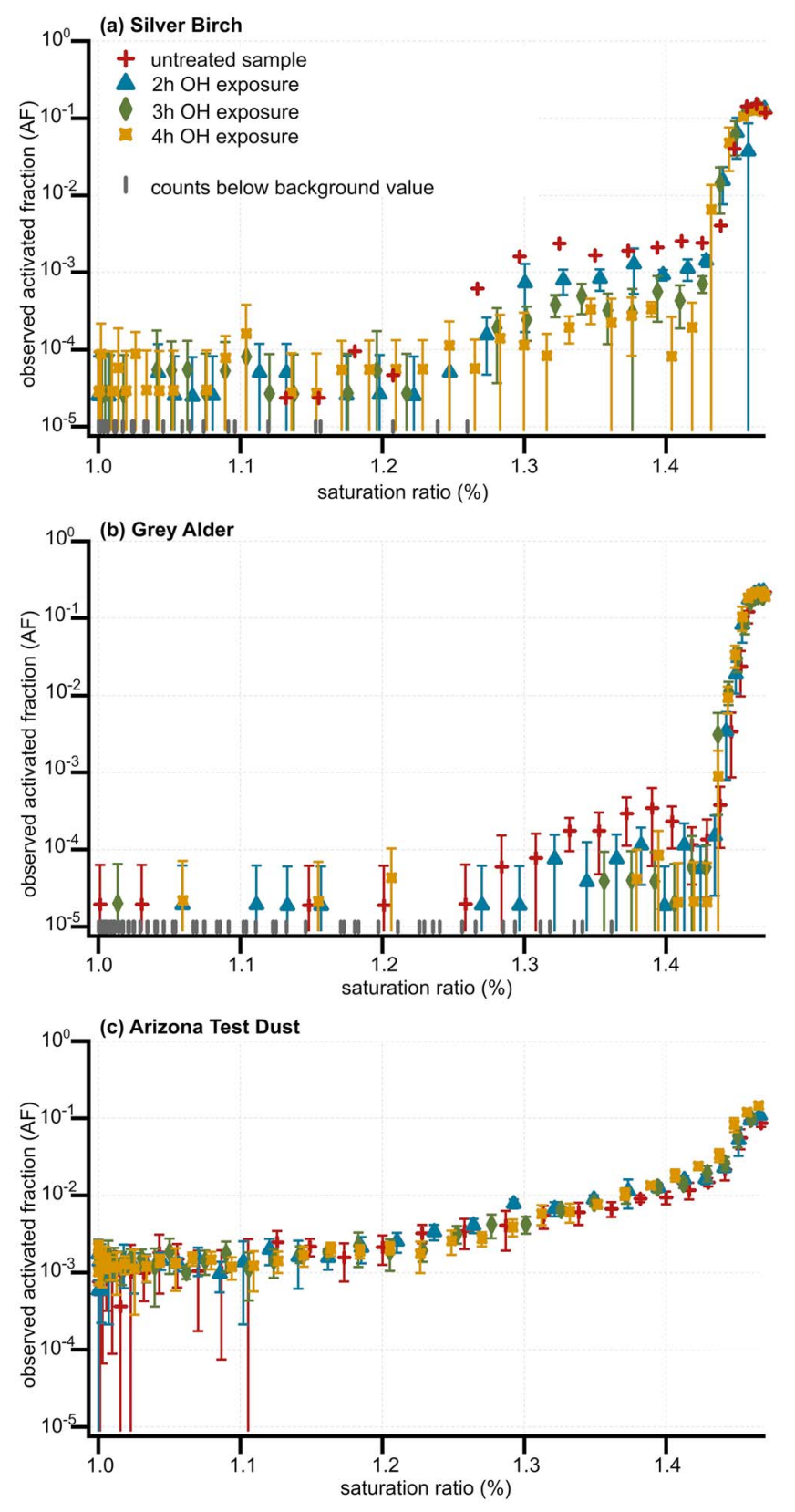

Figure 2. Ice nucleating (IN) activity of untreated and oxidized pollen and dust samples: (a) birch pollen, (b) alder pollen, and (c) Arizona Test Dust-at increasing ice supersaturation ratios. Untreated samples are shown as red stars, $\mathrm{IN}$ activity after $2 \mathrm{~h}$ of $\mathrm{OH}$ exposure is shown as blue triangles, $3 \mathrm{~h}$ exposure time as green rhombs, and $4 \mathrm{~h}$ of $\mathrm{OH}$ oxidation are indicated as yellow squares. The error bars are one standard deviation. inside the chamber only grow to sizes below $2 \mu \mathrm{m}$, permitting discrimination between ice and water based on size. Growth rates were calculated using growth rate equations from Rogers and Yau (1989). Ice crystals are detected by a six-channel Optical Particle Counter (MetOne GT-526S) at the outlet of the UT-CFDC, and counts in the size bins above $2 \mu \mathrm{m}$ are selected for data analysis, representing ice particles. The supersaturation in the chamber is accurate to the $1 \%$ level, as determined by studying the homogeneous freezing of $200 \mathrm{~nm}$ sulfuric acid aerosol. Typical maximum fractional activation values for this chamber are close to 0.1 , with values below unity arising from loss of ice particles (Kanji \& Abbatt, 2009). Chemical analysis was performed on samples directly taken from the atomizer bottle without size selection. For measurements of untreated pollen and dust samples, no $\mathrm{OH}$ was generated in the solution.

\section{Ice Nucleation Activity of Chemically Oxidized Pollen}

The change of IN activity initiated by chemical or physical processing alters the particles' relevance for cloud processes. In this study, we investigated the change of IN activity of two types of pollen as well as ATD under the exposure to $\mathrm{OH}$ for in-cloud conditions (Figure 2). The particles were treated with $\mathrm{OH}$ in the aqueous phase, and their IN activity was measured with the CFDC operated in deposition freezing mode at $234 \mathrm{~K}$ and supersaturation with respect to ice $\left(\mathrm{RH}_{\mathrm{i}}\right)$ ranging from $100 \% \mathrm{RH}_{\mathrm{i}}$ to $150 \% \mathrm{RH}_{\mathrm{i}}$ during each experiment. Given the high hygroscopicity of polysaccharides which are likely constituents of the sampled particles, hygroscopic growth inside the chamber prior to freezing may have occurred. The hygroscopic growth may have led the ice nucleation to occur in immersion/condensation mode rather than true deposition mode. Five $5 \mathrm{~s}$ long measurement intervals were averaged and plotted as the observed activated fraction (AF) against the ice saturation ratio, obtained from measured chamber temperatures during an experiment. AFs of particles are shown on log scale, and intervals where the observed AF was averaged to zero are indicated with gray line markers at the lowest value shown on the $y$ axis. Exposure of the samples to $\mathrm{OH}$ was maintained for $4 \mathrm{~h}$, while measurements of IN activity were taken hourly starting $2 \mathrm{~h}$ after adding $\mathrm{OH}$ to the sample. To determine the ice onsets for untreated and oxidized pollen, a threshold of the observed "ice AF" being 4 times the value of the measured instrumental background was the requirement that needed to be reached to count the measurement as ice active (see Table 1). This criterion for ice nucleation activity is convenient to indicate the change in activity with oxidation and has no specific atmospheric significance. In both cases, a plateau of the AF is observed until water saturation is reached at $\mathrm{RH}_{\mathrm{i}} 146 \%$ and $234 \mathrm{~K}$.

A comparison of the two data sets for birch and alder pollen reveals that both pollen types are IN active at $\mathrm{RH}_{\mathrm{i}}$ between $127 \%$ and 128\%; however, the data show differences in their AFs with birch pollen showing a higher $\mathrm{AF}\left(2 \times 10^{-3}\right)$ than alder pollen $\left(2 \times 10^{-4}\right)$. Both pollen types responded to $\mathrm{OH}$ exposure with a decrease of their IN activity where ice onsets were shifted to $133 \% \mathrm{RH}_{\mathrm{i}}$ for birch pollen and to $138 \% \mathrm{RH}_{\mathrm{i}}$ for alder pollen, respectively, for $4 \mathrm{~h}$ exposure time to $\mathrm{OH}$. After $4 \mathrm{~h}$ of $\mathrm{OH}$ exposure, the plateaus of the AFs after ice onset are decreased by roughly an order of magnitude to AFs of $2 \times 10^{-4}$ for birch and to $4 \times 10^{-5}$ for alder pollen. The nonbiological ATD showed a continuous increase of the AF at increasing $\mathrm{RH}_{\mathrm{i}}$, with values at $100 \% \mathrm{RH}_{\mathrm{i}}$ likely 
Table 1

Background Levels and Ice Onsets for Each Ice Nucleation Experiment Illustrated in Figure 2 for Both Birch and Alder Pollen

\begin{tabular}{|c|c|c|c|c|c|}
\hline & Treatment & Background & $\begin{array}{c}\text { Ice onset at } \mathrm{RH}_{\mathrm{i}} \\
(\mathrm{AF}>4 \times \text { background })\end{array}$ & $\begin{array}{c}\text { Plateau of activated } \\
\text { fraction }\end{array}$ & $\begin{array}{l}\text { Activated fraction plateau } \\
\text { relative to untreated (\%) }\end{array}$ \\
\hline \multirow[t]{4}{*}{ Silver birch } & Untreated & $2 \times 10^{-6}$ & $127 \pm 1 \%$ & $(2 \pm 0.4) \times 10^{-3}$ & 100 \\
\hline & $2 \mathrm{~h} \mathrm{OH}$ & $1 \times 10^{-5}$ & $127 \pm 1 \%$ & $(1 \pm 0.3) \times 10^{-3}$ & 50 \\
\hline & $3 \mathrm{~h} \mathrm{OH}$ & $3 \times 10^{-5}$ & $128 \pm 1 \%$ & $(4 \pm 2) \times 10^{-4}$ & 20 \\
\hline & $4 \mathrm{~h} \mathrm{OH}$ & $4 \times 10^{-5}$ & $133 \pm 1 \%$ & $(3 \pm 1) \times 10^{-4}$ & 15 \\
\hline \multirow[t]{4}{*}{ Grey alder } & Untreated & $4 \times 10^{-6}$ & $128 \pm 1 \%$ & $(2 \pm 1) \times 10^{-4}$ & 100 \\
\hline & $2 \mathrm{~h} \mathrm{OH}$ & $6 \times 10^{-6}$ & $132 \pm 1 \%$ & $(8 \pm 5) \times 10^{-5}$ & 40 \\
\hline & $3 \mathrm{~h} \mathrm{OH}$ & $4 \times 10^{-6}$ & $136 \pm 1 \%$ & $(4 \pm 2) \times 10^{-5}$ & 20 \\
\hline & $4 \mathrm{~h} \mathrm{OH}$ & $1 \times 10^{-6}$ & $138 \pm 1 \%$ & $(4 \pm 3) \times 10^{-5}$ & 20 \\
\hline
\end{tabular}

Note. Background levels are calculated from ice particle counts for sizes above $2 \mu \mathrm{m}$ and ice supersaturations from $100 \%$ to $110 \%$ where no activity of the pollen was observed. Ice onsets are determined as AF values above 4 times the background values for the respective experiment.

due to aerosol background. The exposure to the hydroxyl radical had no effect on the IN activity of the test dust. Control experiments were conducted for all substances that showed ice nucleation activity. No effect was observed for any sample (pollen and ATD), when the test material was exposed to UV light ( $254 \mathrm{~nm}$ ) or hydrogen peroxide only, or when left without any treatment for $4 \mathrm{~h}$. In addition, the influence of sunlight on the pollen IN activity was tested using a solar simulator (Atlas, Suntest CPS) with $4 \mathrm{~h}$ exposure time of the samples to light of wavelength between approximately 290 and $800 \mathrm{~nm}$. No change of the IN activity was found for exposure to solar light.

In agreement with past immersion mode experiments, we find that both untreated birch and alder pollen are ice nucleation active (Augustin et al., 2013; Diehl et al., 2002; Pummer et al., 2012; von Blohn et al., 2005). We believe these are the first laboratory studies of the deposition mode IN activity of such materials, although a shift to immersion/condensation freezing may be occurring given the high hygroscopicity of polysaccharides found in pollen which enable hygroscopic growth prior to freezing. More importantly, the data demonstrate that cloud water $\mathrm{OH}$ effectively lowers their IN activity. In particular, oxidative processing suppresses the AF of SPPs at $234 \mathrm{~K}$ by approximately 1 order of magnitude and shifts the ice onset to higher supersaturation values. Both silver birch and grey alder pollen respond similarly to oxidation, while the nonbiological material does not change under $\mathrm{OH}$ exposure. All results were reproducible across three experiments for each pollen type. We note that the two prior studies of ozone aging of biological particles have also either shown suppression of IN activity or no effect (Attard et al., 2012; Sarron et al., 2013).

With the oxidation affecting only the biological samples tested, it is possible to hypothesize that biological particles, such as pollen, carry chemical structures that are altered through chemical oxidation while inorganic substances remain unaffected. Given the preparation mode, via pollen-washing and $200 \mathrm{~nm}$ size selection, we believe that clusters of macromolecules are likely being oxidized. Consequently, chemical analysis was conducted to further investigate the potential changes in the molecular structure of the pollen component.

\section{Chemical Changes in Oxidized Pollen}

From oxidation studies on organic material it is known that the hydroxy radical readily oxidizes dissolved organics in cloud water and in aerosol particles, with functionalization of the compounds involved followed by molecular fragmentation if sufficient oxidation occurs (George \& Abbatt, 2010; Pöschl \& Shiraiwa, 2015; Zhao et al., 2017). Chemical analysis attempts to potential changes of the molecular structure of the IN active pollen resulting from oxidation. Motivated by the qualitative observation of color loss of pollen samples during $\mathrm{OH}$ exposure when IN activity was measured, the presence and change of conjugation in the substrates is investigated using ultraviolet-visible (UV-Vis) spectrometry (Ocean Optics, USB2000+ UV-Vis-ES using a broadband source). As well, analysis with Fourier transform infrared spectroscopy in attenuated total reflection mode (ATR; NICOLET ${ }^{\text {m' }}$ iS ${ }^{\text {Tm }}$ FT-IR spectrometer, Thermo Fisher) is conducted to relate changes of IN activity to functional group changes of the pollen material.

For UV-Vis analysis, $1 \mathrm{~mL}$ of the sample was transferred to a $1 \mathrm{~cm}$ standard cuvette, and the spectral range from $200 \mathrm{~nm}$ to $550 \mathrm{~nm}$ was measured. The results of the UV-Vis analysis are shown in Figure 3a for 

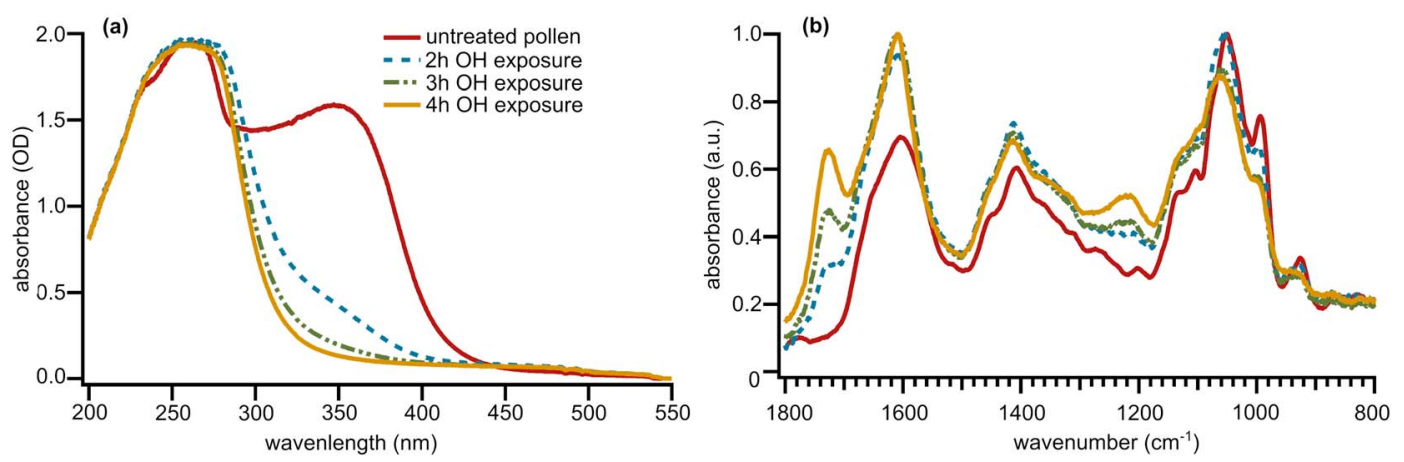

Figure 3. Chemical analysis results from untreated and oxidized birch pollen samples analyzed with (a) ultraviolet-visible and (b) Fourier transform infrared attenuated total reflection.

untreated and oxidized birch pollen. A decline of absorbance can be observed for the spectral range between $300 \mathrm{~nm}$ and $400 \mathrm{~nm}$ over the course of a $4 \mathrm{~h}$ exposure time to $\mathrm{OH}$. Alder pollen show very similar results which are presented in Figure $\mathbf{S} 4$ in the supporting information. The observed decline of absorbance indicates a loss of conjugated double bonds in the pollen compound structure and is consistent with the qualitatively observed color loss over the course of an $\mathrm{OH}$ exposure experiment. The yellow color of pollen arises from the presence of flavonoids (Gould \& Lister, 2006) which consist of two phenyl- and one heterocyclic rings that strongly absorb in the UV spectral range and protect the pollen from harmful UV-B radiation (Flenley, 2011). Flavonoids are mainly associated with the outer wall of pollen and are readily extractable (Wiermann \& Vieth, 1983).

Fourier transform infrared ATR analysis required higher pollen concentrations for good signal quality. Therefore, $0.8 \mathrm{~g}$ of birch or alder pollen was suspended in $200 \mathrm{~mL} \mathrm{MilliQ}{ }^{\circledR}$ water and exposed to $\mathrm{OH}$ as described in section 2. From each sample, $20 \mu \mathrm{L}$ was dried onto the ATR crystal applying a small flow of dry nitrogen. For birch pollen, the ATR spectra for the spectral range from $1800 \mathrm{~cm}^{-1}$ to $800 \mathrm{~cm}^{-1}$ are consistent with data obtained in Dreischmeier et al. (2017), where birch washing water was investigated and found to indicate the presence of polysaccharides. Changes to the ATR spectra during OH exposure times are apparent for the spectral ranges $1,780 \mathrm{~cm}^{-1}$ to $1,690 \mathrm{~cm}^{-1}$ and $1,020 \mathrm{~cm}^{-1}$ to $957 \mathrm{~cm}^{-1}$. The decline of signals at approximately 990 and $920 \mathrm{~cm}^{-1}$ can be explained by the bending mode associated with $\mathrm{C}=\mathrm{C}-\mathrm{H}$ bonds disappearing, which suggests these functionalities being chemically modified by $\mathrm{OH}$ oxidation. Although harder to see, there is also a decrease in the shoulder at roughly $1,650 \mathrm{~cm}^{-1}$, which is likely loss of the carbon-carbon double bond stretch. Increasing absorbance between $1,780 \mathrm{~cm}^{-1}$ and $1,690 \mathrm{~cm}^{-1}$ suggests a gain of carbonyl groups, thus indicating that chemical oxidation is occurring. As well, there is evidence for formation of carbon-oxygen single bonds at roughly $1,200 \mathrm{~cm}^{-1}$.

We cannot directly relate these observed rates of chemical modification to the rates of loss of IN activity, given that ice nucleation is likely occurring via a small subset of surficial compounds or structures on the surface of the SPP. However, we believe it is fair to assume that the ice nucleating molecules/structures are likely being oxidized at a similar rate as the overall changes illustrated in Figure 3 and that such oxidation is the cause of the loss of IN activity. Indeed, it is intriguing that the rates of both chemical and IN activity modification are qualitatively so similar, that is, substantial change for each in the first $2 \mathrm{~h}$ of oxidation.

\section{Atmospheric Implications}

The aim of this work has been to examine the effect of chemical oxidation by $\mathrm{OH}$ on the IN activity of pollen compounds, under cloud water conditions. In particular, although it is very well acknowledged that $\mathrm{OH}$ oxidative processing occurs of organic aerosol and dissolved cloud water organics (George \& Abbatt, 2010; Herrmann et al., 2010; Zhao et al., 2017), the role of such chemical processing on ice nucleating activity has not been assessed for biological particles. For the first time, measurements of IN activity have shown that ice nucleation activity of birch and alder pollen washing water is decreased by chemical oxidation in cloud water. The concentrations of aqueous $\mathrm{OH}$ in our experiments are at the upper limit of $\mathrm{OH}$ concentrations in cloud water. These relatively high $\mathrm{OH}$ concentrations limit the experiments to a first approximation of 
the maximum effect $\mathrm{OH}$ has on the IN activity of pollen. Both types of pollen respond nearly equally to the exposure to $\mathrm{OH}$, however differ in their overall IN activity, where birch pollen are found to be more IN active than the alder pollen. Chemical analysis supports a change of the molecular structures due to $\mathrm{OH}$ exposure on similar time scales as the IN activity measurements, with the loss of carbon-carbon double bonds and the formation of carbonyl and other oxidized functional groups.

From this result, we suggest that chemical oxidation by $\mathrm{OH}$ in cloud water needs to be considered to refine parameterizations of relevant INP processing to improve global climate models (Boucher et al., 2013), as this process has the potential to lower IN activity. We anticipate that the impact will only occur after considerable time of in-cloud processing, given the rates of the IN deactivation displayed in Figure 2. As well, it is possible that such processing may occur at the flower/plant source as well, for example, when dew and sunlight are present. By contrast, experiments confirm that $\mathrm{OH}$ oxidation does not affect the activity of the tested atmospheric mineral dust ATD, as tested for a relatively inert inorganic substrate. Therefore, a good knowledge of the molecular structure of biological IN material such as pollen is highly desirable but remains unclear. Future studies should aim to look at the molecular level of the pollen fragments by using, for example, highresolution microscopy to unveil potential changes of the chemical structure due to oxidation processes. Furthermore, other atmospheric oxidation processes, such as heterogeneous oxidation by $\mathrm{OH}$ radicals, also need to be investigated.

\section{Acknowledgments}

The authors would like to acknowledge the Natural Sciences and Engineering Research Council (NSERC) for funding under grant RGPIN-2017-05972. The authors declare no conflict of interest regarding affiliation or funding. We acknowledge Z. Dráb from Pharmallerga for providing the pollen. Figure source data for all plots shown in this publication have been deposited in the University of Toronto Dataverse (doi:10.5683/SP/JLPHBI; Gute \& Abbatt, 2018).

\section{References}

Arakaki, T., Anastasio, C., Kuroki, Y., Nakajima, H., Okada, K., Kotani, Y., ... Miyagi, Y. (2013). A general scavenging rate constant for reaction of hydroxyl radical with organic carbon in atmospheric waters. Environmental Science \& Technology, 47(15), 8196-8203. https://doi.org/ 10.1021/es401927b

Archuleta, C. M., DeMott, P. J., \& Kreidenweis, S. M. (2005). Ice nucleation by surrogates for atmospheric mineral dust and mineral dust/sulfate particles at cirrus temperatures. Atmospheric Chemistry and Physics, 5, 2617-2634. https://doi.org/10.5194/acp-5-2617-2005

Attard, E., Yang, H., Delort, A. M., Amato, P., Pöschl, U., Glaux, C., ... Morris, C. E. (2012). Effects of atmospheric conditions on ice nucleation activity of pseudomonas. Atmospheric Chemistry and Physics, 12, 10,667-10,677. https://doi.org/10.5194/acp-12-10667-2012

Augustin, S., Wex, H., Niedermeier, D., Pummer, B., Grothe, H., Hartmann, S., .. Stratmann, F. (2013). Immersion freezing of birch pollen washing water. Atmospheric Chemistry and Physics, 13(21), 10,989-11,003. https://doi.org/10.5194/acp-13-10989-2013

Boucher, O., Randall, D., Artaxo, P., Bretherton, C., Feingold, G., Forster, P., ... Zhang, X. Y. (2013). Clouds and aerosols. In T. F. Stocker, et al. (Eds.), Climate change 2013: The physical science basis. Contribution of working group I to the fifth assessment report of the intergovernmental panel on climate change (pp. 571-657). Cambridge, United Kingdom and New York: Cambridge University Press. https://doi.org/10.1017/ CBO9781107415324.016

Breiteneder, H., Pettenburger, K., Bito, A., Valenta, R., Kraft, D., Rumpold, H., ... Breitenbach, M. (1989). The gene coding for the major birch pollen allergen Betvl, is highly homologous to a pea disease resistance response gene. The EMBO Journal, 8(7), $1935-1938$.

Brooks, S. D., Suter, K., \& Olivarez, L. (2014). Effects of chemical aging on the ice nucleation activity of soot and polycyclic aromatic hydrocarbon aerosols. The Journal of Physical Chemistry. A, 118, 10,036-10,047. https://doi.org/10.1021/jp508809y

Buxton, G. V., Greenstock, C. L., Helman, W. P., \& Ross, A. B. (1988). Critical review of rate constants for reactions of hydrated electrons, hydrogen atoms and hydroxyl radicals $\mathrm{OH} / \mathrm{O}-$ in aqueous solution. Journal of Physical and Chemical Reference Data, 17(2), 513-886. https://doi.org/10.1063/1.555805

Clarke, A., Gleeson, P., Harrison, S., \& Knox, R. B. (1979). Pollen-stigma interactions: Identification and characterization of surface components with recognition potential. Proceedings of the National Academy of Sciences of the United States of America, 76(7), 3358-3362. https://doi. org/10.1073/pnas.76.7.3358

Cziczo, D. J., Froyd, K. D., Gallavardin, S. J., Moehler, O., Benz, S., Saathoff, H., \& Murphy, D. M. (2009). Deactivation of ice nuclei due to atmospherically relevant surface coatings. Environmental Research Letters, 4, 44013. https://doi.org/10.1088/1748-9326/4/4/044013

DeMott, P. J., Möhler, O., Stetzer, O., Vali, G., Levin, Z., Petters, M. D., ... Saunders, C. (2011). Resurgence in ice nuclei measurement research. Bulletin of the American Meteorological Society, 92(12), 1623-1635. https://doi.org/10.1175/2011BAMS3119.1

Després, V., Alex Huffman, J., Burrows, S. M., Hoose, C., Safatov, A. S., Buryak, G., ... Jaenicke, R. (2012). Primary biological aerosol particles in the atmosphere: A review. Tellus Series B: Chemical and Physical Meteorology, 64, 15598. https://doi.org/10.3402/tellusb.v64i0.15598

Diehl, K., Matthias-Maser, S., Jaenicke, R., \& Mitra, S. K. (2002). The ice nucleating ability of pollen. Atmospheric Research, 61(2), 125-133. https://doi.org/10.1016/S0169-8095(01)00132-6

Dreischmeier, K., Budke, C., Wiehemeier, L., Kottke, T., \& Koop, T. (2017). Boreal pollen contain ice-nucleating as well as ice-binding "antifreeze" polysaccharides. Scientific Reports, 7, 41,890. https://doi.org/10.1038/srep41890

Flenley, J. R. (2011). Why is pollen yellow? And why are there so many species in the tropical rain forest? Journal of Biogeography, 38, 809-816. https://doi.org/10.1111/j.1365-2699.2011.02480.x

George, I. J., \& Abbatt, J. P. D. (2010). Heterogeneous oxidation of atmospheric aerosol particles by gas-phase radicals. Nature Chemistry, 2, 713-722. https://doi.org/10.1038/nchem.806

Gould, K. S., \& Lister, C. (2006). Flavonoid functions in Plants. In Ø. M. Andersen \& K. R. Markham (Eds.), Flavonoids: Chemistry, Biochemistry and Applications (pp. 397-441). Boca Raton, FL: CRC Press.

Gute, E., \& Abbatt, J. P. D. (2018). Supplementary data to the scientific publication: Oxidative processing lowers the ice nucleation activity of birch and alder pollen, University of Toronto Dataverse. https://doi.org/10.5683/SP/JLPHBI

Herrmann, H., Hoffmann, D., Schaefer, T., Bräuer, P., \& Tilgner, A. (2010). Tropospheric aqueous-phase free-radical chemistry: Radical sources, spectra, reaction kinetics and prediction tools. Chemphyschem, 11, 3796-3822. https://doi.org/10.1002/cphc.201000533

Hoose, C., \& Möhler, O. (2012). Heterogeneous ice nucleation on atmospheric aerosols: A review of results from laboratory experiments. Atmospheric Chemistry and Physics, 12, 9817-9854. https://doi.org/10.5194/acp-12-9817-2012 
Kanji, Z. A., \& Abbatt, J. P. D. (2009). The University of Toronto Continuous Flow Diffusion Chamber (UT-CFDC): A simple design for ice nucleation studies. Aerosol Science and Technology, 43, 730-738. https://doi.org/10.1080/02786820902889861

Kanji, Z. A., Florea, O., \& Abbatt, J. P. D. (2008). Ice formation via deposition nucleation on mineral dust and organics: Dependence of onset relative humidity on total particulate surface area. Environmental Research Letters, 3, 25004. https://doi.org/10.1088/1748-9326/3/2/ 025004

Kanji, Z. A., Ladino, L. A., Wex, H., Boose, Y., Burkert-Kohn, M., Cziczo, D. J., \& Krämer, M. (2017). Overview of ice nucleating particles. Meteorological Monographs, 58, 1.1-1.33. https://doi.org/10.1175/AMSMONOGRAPHS-D-16-0006.1

Lelieveld, J., \& Crutzen, P. J. (1991). The role of clouds in tropospheric photochemistry. Journal of Atmospheric Chemistry, 12(3), 229-267. https://doi.org/10.1007/BF00048075

Lohmann, U. (2006). Aerosol effects on clouds and climate. Space Science Reviews, 125, 129-137. https://doi.org/10.1007/s11214-006-9051-8

Möhler, O., DeMott, P. J., Vali, G., \& Levin, Z. (2007). Microbiology and atmospheric processes: The role of biological particles in cloud physics. Biogeosciences Discussions, 4, 2559-2591. https://doi.org/10.5194/bgd-4-2559-2007

Pöschl, U., \& Shiraiwa, M. (2015). Multiphase chemistry at the atmosphere-biosphere interface influencing climate and public health in the Anthropocene. Chemical Reviews, 115(10), 4440-4475. https://doi.org/10.1021/cr500487s

Pruppacher, H. R., \& Klett, J. D. (1997). Microphysics of Clouds and Precipitation (2nd ed.). Dordrecht, Netherlands: Kluwer Academic Publishers. Pummer, B. G., Bauer, H., Bernardi, J., Bleicher, S., \& Grothe, H. (2012). Suspendable macromolecules are responsible for ice nucleation activity of birch and conifer pollen. Atmospheric Chemistry and Physics, 12, 2541-2550. https://doi.org/10.5194/acp-12-2541-2012

Rogers, R. R., \& Yau, M. K. (1989). A Short Course in Cloud Physics. Oxford: Pergamon Press.

Sarron, E., Cochet, N., \& Gadonna-Widehem, P. (2013). Effects of aqueous ozone on Pseudomonas syringae viability and ice nucleating activity. Process Biochemistry, 48(7), 1004-1009. https://doi.org/10.1016/j.procbio.2013.05.018

Schäppi, G. F., Taylor, P. E., Pain, M. C. F., Cameron, P. A., Dent, A. W., Staff, I. A., \& Suphioglu, C. (1999). Concentrations of major grass group 5 allergens in pollen grains and atmospheric particles: Implications for hay fever and allergic asthma sufferers sensitized to grass pollen allergens. Clinical and Experimental Allergy, 29(5), 633-641. https://doi.org/10.1046/j.1365-2222.1999.00567.x

Schulte, F., Mäder, J., Kroh, L. W., Panne, U., \& Kneipp, J. (2009). Characterization of pollen carotenoids with in situ and high-performance thin-layer chromatography supported resonant Raman spectroscopy. Analytical Chemistry, 81, 8426-8433. https://doi.org/10.1021/ ac901389p

Sihvonen, S. K., Schill, G. P., Lyktey, N. A., Veghte, D. P., Tolbert, M. A., \& Freedman, M. A. (2014). Chemical and physical transformations of aluminosilicate clay minerals due to acid treatment and consequences for heterogeneous ice nucleation. The Journal of Physical Chemistry. A, 118(38), 8787-8796. https://doi.org/10.1021/jp504846g

Steiner, A. L., Brooks, S. D., Deng, C., Thornton, D. C. O., Pendleton, M. W., \& Bryant, V. (2015). Pollen as atmospheric cloud condensation nuclei. Geophysical Research Letters, 42, 3596-3602. https://doi.org/10.1002/2015GL064060

Sullivan, R. C., Miñambres, L., Demott, P. J., Prenni, A. J., Carrico, C. M., Levin, E. J. T., \& Kreidenweis, S. M. (2010). Chemical processing does not always impair heterogeneous ice nucleation of mineral dust particles. Geophysical Research Letters, 37, L24805. https://doi.org/10.1029/ 2010GL045540

Sullivan, R. C., Petters, M. D., DeMott, P. J., Kreidenweis, S. M., Wex, H., Niedermeier, D., ... Sierau, B. (2010). Irreversible loss of ice nucleation active sites in mineral dust particles caused by sulphuric acid condensation. Atmospheric Chemistry and Physics, 10, 11,471-11,487. https:// doi.org/10.5194/acp-10-11471-2010

von Blohn, N., Mitra, S. K., Diehl, K., \& Borrmann, S. (2005). The ice nucleating ability of pollen: Part III: New laboratory studies in immersion and contact freezing modes including more pollen types. Atmospheric Research, 78, 182-189. https://doi.org/10.1016/ j.atmosres.2005.03.008

Wang, B., \& Knopf, D. A. (2011). Heterogeneous ice nucleation on particles composed of humic-like substances impacted by O3. Journal of Geophysical Research: Atmospheres, 116, D03205. https://doi.org/10.1029/2010JD014964

Wex, H., DeMott, P. J., Tobo, Y., Hartmann, S., Rösch, M., Clauss, T., ... Stratmann, F. (2014). Kaolinite particles as ice nuclei: Learning from the use of different kaolinite samples and different coatings. Atmospheric Chemistry and Physics, 14(11), 5529-5546. https://doi.org/10.5194/ acp-14-5529-2014

Wiermann, R., \& Vieth, K. (1983). Outer pollen wall, an important accumulation site for flavonoids. Protoplasma, 118(3), 230-233. https://doi. org/10.1007/BF01281807

Zhao, R., Lee, A. K. Y., Wang, C., Wania, F., Wong, J. P. S., Zhou, S., \& Abbatt, J. P. D. (2017). The role of water in organic aerosol multiphase chemistry: Focus on partitioning and reactivity. In Advances in Atmospheric Chemistry (pp. 95-184). New Jersey: World Scientific. 